\title{
Tissue Inhibitor of Metalloproteinase 1 Measurement
}

National Cancer Institute

\section{Source}

National Cancer Institute. Tissue Inhibitor of Metalloproteinase 1 Measurement. NCI

Thesaurus. Code C82036.

The determination of the amount of tissue inhibitor of metalloproteinase 1 present in a sample. 